\title{
PERTUMBUHAN JATI (Tectona grandis Linn. f.) ASAL KULTUR JARINGAN PADA BEBERAPA UKURAN LUBANG TANAM DAN DOSIS PUPUK KANDANG DI PARUNGPANJANG, BOGOR, JAWA BARAT
}

\author{
Growth of Teak (Tectona grandis Linn. f.) from Tissue Culture Propagation \\ on the Several Sizes of Planting Holes and Manure Dosages in Parungpanjang, \\ Bogor, West Java
}

\author{
Dede J. Sudrajat dan/and Yulianti Bramasto \\ Balai Penelitian Teknologi Perbenihan Bogor \\ Jl. Pakuan Ciheuleut PO. BOX 105 Bogor, 16001 Telp./Fax (0251) 8327768
}

Naskah diterima : 16 Juni 2008; Naskah diterima : 8 Juni 2009

\begin{abstract}
The improvement on planting-site condition is an important effort in balancing or overcoming the deterioration quality of production forest area. This research was aimed to look into the effect of plantingholes sizes and manure dosages on the growth of teak (Tectona grandis) from tissue culture propagation up to 3 years old age, conducted at Parungpanjang Forest Research Station, Bogor. The planting was done in 2001 with spaces of $3 \mathrm{~m}$ by $3 \mathrm{~m}$. The lay out of experiment consisted of 4 blocks. Each block allocated for 5 treatments plot and each plot is contained 49 trees. About the treatments, there was consecutively control (without manure) with planting holes measuring $25 \times 25 \times 25 \mathrm{~cm}$ (F1); $1 \mathrm{~kg}$ of manure with holes $50 \times 50 \times$ $50 \mathrm{~cm}$ (F2); $2 \mathrm{~kg}$ of manure with holes $50 \times 50 \times 50 \mathrm{~cm}(\mathrm{F3}), 3 \mathrm{~kg}$ of manure with holes $75 \times 75 \times 75 \mathrm{~cm}$ (F4); and $4 \mathrm{~kg}$ of manure with holes $75 \times 75 \times 75 \mathrm{~cm}$ (F5). The measurement was conducted by census when the tree reached 1, 2, and 3 year ages, respectively. The measured data comprised survival percentage, height, diameter, and volume of tree. The result showed a trend that the bigger planting holes and the higher manure dosages provided the higher growth. The F4 and F5 treatment provided the best survival and growth. In the practice in the compact and poor soil such as at Parungpanjang, the F4 treatment is a promising method to increase the success of teak planting. The treatment produced the trees survival $92 \%$, height $5.4 \mathrm{~m}$, diameter $7.1 \mathrm{~cm}$, and tree volume $0.0023 \mathrm{~m}^{3}$ on the 3 years old of the teak planting.
\end{abstract}

Key words : growth, manure, planting holes, teak

\begin{abstract}
ABSTRAK
Perbaikan kondisi tapak penanaman merupakan upaya penting untuk mengimbangi penurunan kualitas lahan hutan tanaman. Penelitian ini bertujuan untuk mengetahui pengaruh ukuran lubang tanam dan dosis pupuk kandang terhadap pertumbuhan tanaman jati (Tectona grandis) asal kultur jaringan hingga umur 3 tahun di Hutan Penelitian Parungpanjang, Bogor. Penanaman dilakukan pada tahun 2001 dengan jarak tanam $3 \times 3 \mathrm{~m}$. Racangan yang digunakan adalah rancangan acak berblok dengan 4 blok. Setiap blok terdiri dari 5 petak perlakuan yang masing-masing berisi 49 pohon. Perlakuan yang digunakan terdiri dari: tanpa pupuk ukuran lubang $25 \times 25 \times 25 \mathrm{~cm}(\mathrm{~F} 1), 1 \mathrm{~kg}$ pupuk ukuran lubang $50 \times 50 \times 50 \mathrm{~cm}(\mathrm{~F} 2), 2 \mathrm{~kg}$ pupuk ukuran lubang 50 × 50 × $50 \mathrm{~cm}$ (F3), 3 kg pupuk dengan ukuran lubang $75 \times 75$ x $75 \mathrm{~cm}$ (F4), dan 4 kg pupuk dengan ukuran lubang $75 \times 75 \times 75 \mathrm{~cm}$ (F5). Pengukuran dilakukan dengan cara sensus pada umur 1, 2, dan 3 tahun. Parameter yang diukur meliputi persen hidup, tinggi, diameter, dan volume pohon. Hasil penelitian menunjukkan kecenderungan bahwa makin besar lubang tanam dan makin banyak pupuk kandang memberikan pertumbuhan yang makin baik. Pemberian pupuk kandang dengan dosis F4 dan F5 memberikan hasil yang terbaik terhadap persentase hidup dan pertumbuhan tanaman jati. Untuk aplikasinya pada tanah-tanah yang padat dan miskin hara seperti di Parungpanjang, perlakuan F4 dapat
\end{abstract}


dipertimbangkan untuk diterapkan dalam meningkatkan keberhasilan penanaman jati. Perlakuan tersebut menghasilkan persen hidup $92 \%$, tinggi $5,4 \mathrm{~m}$, diameter $7,1 \mathrm{~cm}$, dan volume pohon $0,0023 \mathrm{~m}^{3}$ pada umur tanaman 3 tahun.

\section{Kata kunci : jati, lubang tanam, pertumbuhan, pupuk kandang}

\section{PENDAHULUAN}

Tanaman jati (Tectona grandis Linn. f.) merupakan salah satu jenis pohon bernilai ekonomi tinggi yang terus dikembangkan melalui intensifikasi pengelolaan hutan sehingga produksi per satuan luas diharapkan terus meningkat. Jati banyak dibudidayakan di Pulau Jawa di kawasan hutan yang dikelola Perum Perhutani, namun saat ini, telah banyak diminati masyarakat sebagai komoditi hutan tanaman rakyat (Sadharjo, 2001). Pada beberapa lokasi, bibit asal kultur jaringan telah mulai ditanam. Beberapa laporan menunjukkan pertumbuhan yang lebih baik dari tanaman asal biji (Danu et al., 2003; Yulianti dan Buharman, 2002), namun laporan lainnya menunjukkan pertumbuhan tidak berbeda nyata (Rimbawanto, 2000).

Kualitas dan kesuburan tanah sebagian besar tapak penanaman jati di Pulau Jawa telah mengalami penurunan (Sukresno et al., 2003). Penurunan kesuburan ini harus diimbangi dengan perbaikan kondisi tapak baik dengan pemupukan maupun pengolahan tanah. Beberapa penelitian menunjukkan bahwa pemupukan pada saat penanaman dapat meningkatkan pertumbuhan awal tanaman tanaman Gmelina arborea, Paraserianthes falcataria, Acacia mangium, Pterygota alata, dan Aquilaria malaccensis (Otsamo et al., 1995; Hendromono, 1996; Surata dan Widnyana, 2001). Pada penanaman mahoni, dosis pupuk organik $2 \mathrm{~kg} /$ lubang tanam memberikan pertumbuhan optimal (Yassir dan Omon, 2007). Upaya lainnya untuk meningkatkan keberhasilan tanaman adalah memperbaiki ukuran lubang tanam. Ukuran yang umum digunakan untuk jenis-jenis tanaman hutan adalah 30 × 30 × $30 \mathrm{~cm}$ (Hendromono, 1996; Santoso, 1997; Surata dan Widnyana, 2001). Namun ukuran yang lebih dalam hingga $40 \mathrm{~cm}$ mampu meningkatkan persentase hidup dan tinggi bibit Cupressus sempervirens (Tabari dan Saeidi, 2008). Menurut Clatterbuck (2000), ukuran lubang tanam pada tanah dengan kondisi fisik jelek (padat) dapat diperbesar hingga 5 kali diameter gulungan akar.

Penelitian ini bertujuan untuk mengetahui pengaruh ukuran lubang tanam dan dosis pupuk kandang terhadap pertumbuhan tinggi, diameter, dan volume tanaman jati asal kultur jaringan hingga umur 3 tahun. Perbaikan kondisi tapak dengan perlakuan pemupukan dan ukuran lubang tanam yang tepat diharapkan akan meningkatkan produktivitas tanaman jati.

\section{BAHAN DAN METODE}

Penanaman dilakukan pada tahun 2001, sedangkan evaluasi pertumbuhan tanaman dilakukan pada tahun 2002 (umur 1 tahun), tahun 2003 (umur 2 tahun), dan tahun 2004 (umur 3 tahun). Uji penanaman berada di Hutan Penelitian Parungpanjang yang berlokasi di Kecamatan Parungpanjang, Kabupaten Bogor, Propinsi Jawa Barat.

Secara geografis, Hutan Penelitian Parungpanjang terletak di antara $1066^{\circ}$ Bujur Timur dan $10620^{\circ}$ Lintang Selatan. Lokasi tersebut berada pada ketinggian 51,71 $\mathrm{m}$ di atas permukaan laut dengan topografi landai dan bergelombang. Hutan Penelitian Parungpanjang memiliki tipe curah hujan A dengan kisaran curah hujan tahunan adalah $2000-2500 \mathrm{~mm} /$ tahun. Hasil analisis tanah pada 4 blok penelitian di hutan penelitian tersebut dapat dilihat pada Lampiran 1.

Bahan yang digunakan adalah bibit jati asal kultur jaringan yang diperoleh dari PT. Monfori Nusantara Bogor dan pupuk kandang dari ternak sapi. Rancangan yang digunakan adalah rancangan acak berblok dengan 4 blok uji. Setiap blok terdiri dari 5 perlakuan sehingga secara keseluruhan terdapat 20 petak uji dengan jarak antar petak $6 \mathrm{~m}$. Penanaman dilakukan dengan jarak tanam $3 \times 3 \mathrm{~m}$. Perlakuan yang digunakan adalah : 
$\mathrm{F} 1=$ Tanpa pupuk dengan ukuran lubang tanam $25 \times 25 \times 25 \mathrm{~cm}$.

$\mathrm{F} 2=$ Pupuk kandang $1 \mathrm{~kg}$ dengan ukuran lubang tanam $50 \times 50 \times 50 \mathrm{~cm}$.

F3 = Pupuk kandang $2 \mathrm{~kg}$ dengan ukuran lubang tanam $50 \times 50 \times 50 \mathrm{~cm}$

$\mathrm{F} 4=$ Pupuk kandang $3 \mathrm{~kg}$ dengan ukuran lubang tanam $75 \times 75 \times 75 \mathrm{~cm}$.

$\mathrm{F} 5=$ Pupuk kandang $4 \mathrm{~kg}$ dengan ukuran lubang tanam $75 \times 75 \times 75 \mathrm{~cm}$.

Pengukuran dilakukan dengan cara sensus terhadap semua jenis tanaman yang diuji. Pengukuran dilakukan ketika tanaman tersebut berumur 1, 2, dan 3 tahun. Parameter yang diukur adalah persen hidup, tinggi, diameter, dan volume tanaman. Untuk penentuan volume pohon digunakan angka bentuk 0,5 . Uji Duncan digunakan bila hasil uji $\mathrm{F}$ analisis ragam berpengaruh nyata.

\section{HASIL DAN PEMBAHASAN}

Ukuran lubang tanam dan dosis pupuk kandang tidak berpengaruh nyata terhadap persen hidup tanaman jati umur 1, 2, dan 3 tahun (Lampiran 2). Hal yang sama dilaporkan oleh Hossain dan Paul (1998), untuk jenis Hopea odorata dan Acacia auriculiformis pada ukuran lubang tanam 30 × 30 × $30 \mathrm{~cm}$, 20 × 20 × $20 \mathrm{~cm}$, dan $15 \times 15 \times 15 \mathrm{~cm}$. Walaupun demikian, perlakuan F4 dan F5 memberikan persen hidup terbaik hingga umur 3 tahun masing-masing $92 \%$, kemudian F1 dan F3 dengan persentase hidup $88 \%$, dan F2 dengan persentase hidup 86\% (Gambar 1). Persentase hidup bibit memiliki kecenderungan makin tinggi dengan makin besarnya ukuran lubang tanam dan dosis pupuk kandang yang diberikan.

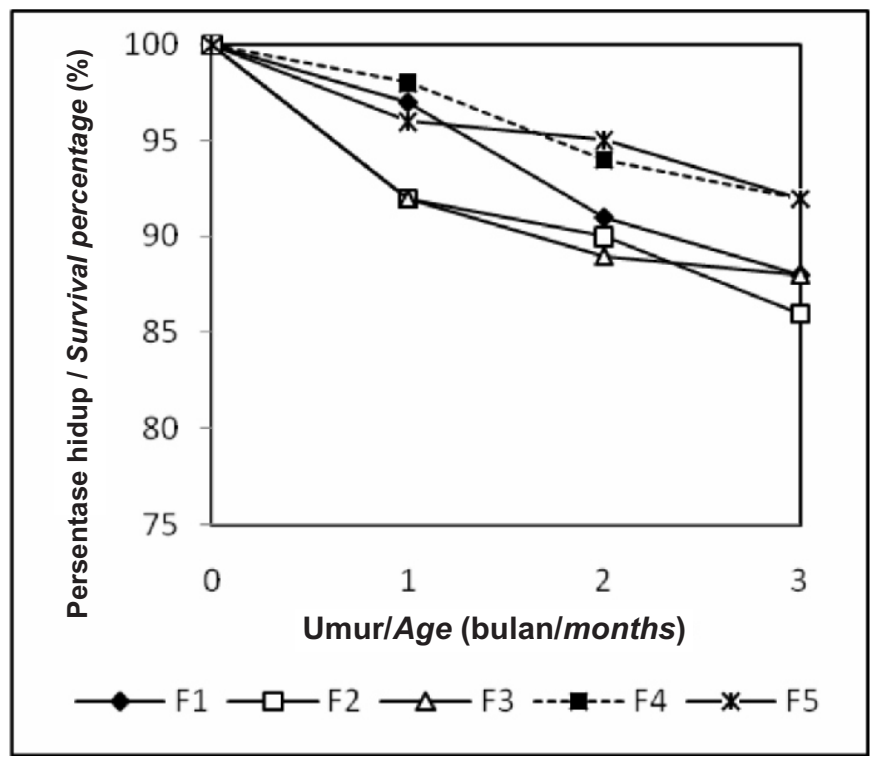

Gambar (Figure) 1. Persen hidup tanaman jati pada setiap perlakuan (Survival percentage of teak on each treatment)

Pertumbuhan tinggi, diameter, dan volume tanaman jati hingga umur 3 tahun pada beberapa perlakuan memberikan hasil yang berbeda (Gambar 2). Pada umur 1-2 tahun pertumbuhan relatif cepat, sedangkan pada umur 3 tahun pertumbuhannya menjadi lebih lambat. Kondisi ini mencerminkan bahwa perlakuan hanya memberikan pengaruh yang cukup tinggi pada awal pertumbuhan. Perlakuan terbaik dihasilkan oleh perlakuan F4 dan F5. Perlakuan ini memberikan hasil yang tidak berbeda nyata untuk tinggi, diameter, dan volume. Jika dibandingkan dengan pertumbuhan di Rumpin, Bogor, tanaman jati di Parungpanjang hingga umur 3 tahun memiliki pertumbuhan yang tidak berbeda jauh. Tinggi tanaman mencapai 5,4 $\mathrm{m}$ dan diameter 7,2 cm, sedangkan di Rumpin, tinggi dan diameter tanaman mencapai 5,39 $\mathrm{m}$ dan 5,15 cm (Danu et al., 2006). 


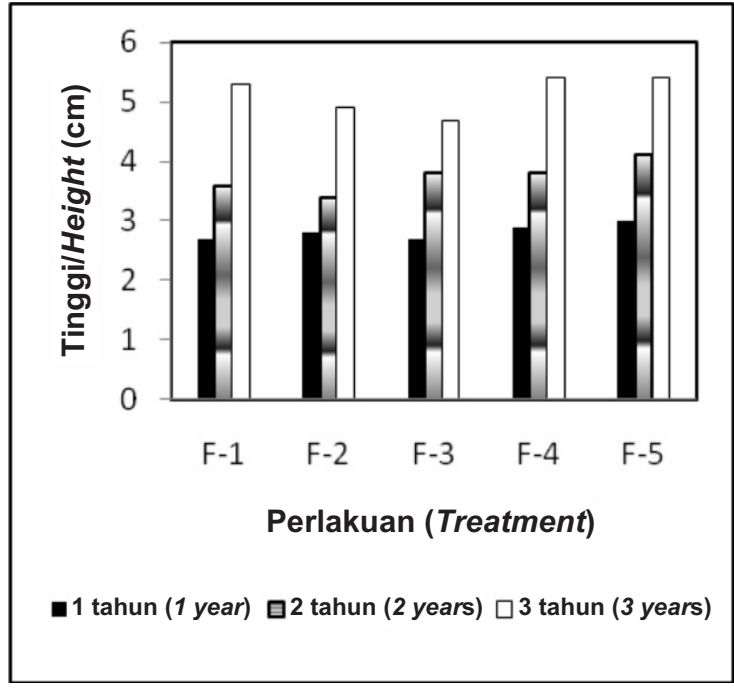

(a)

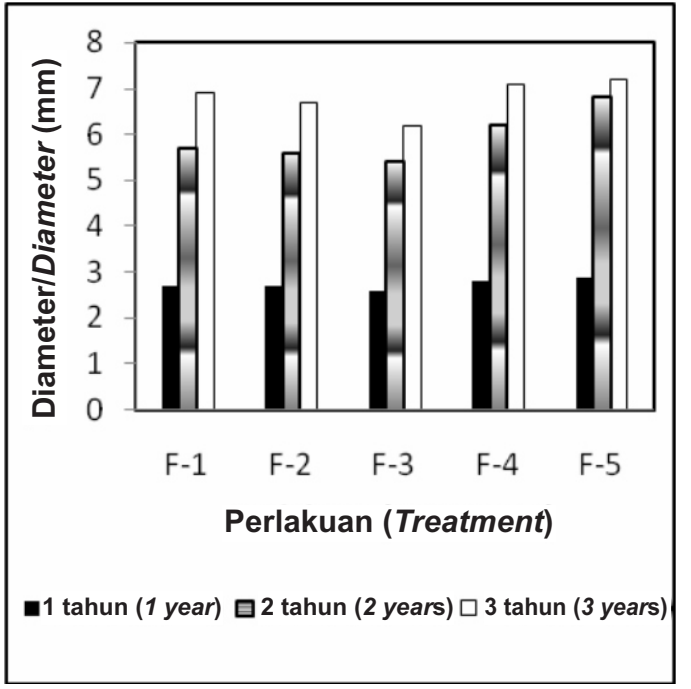

(b)

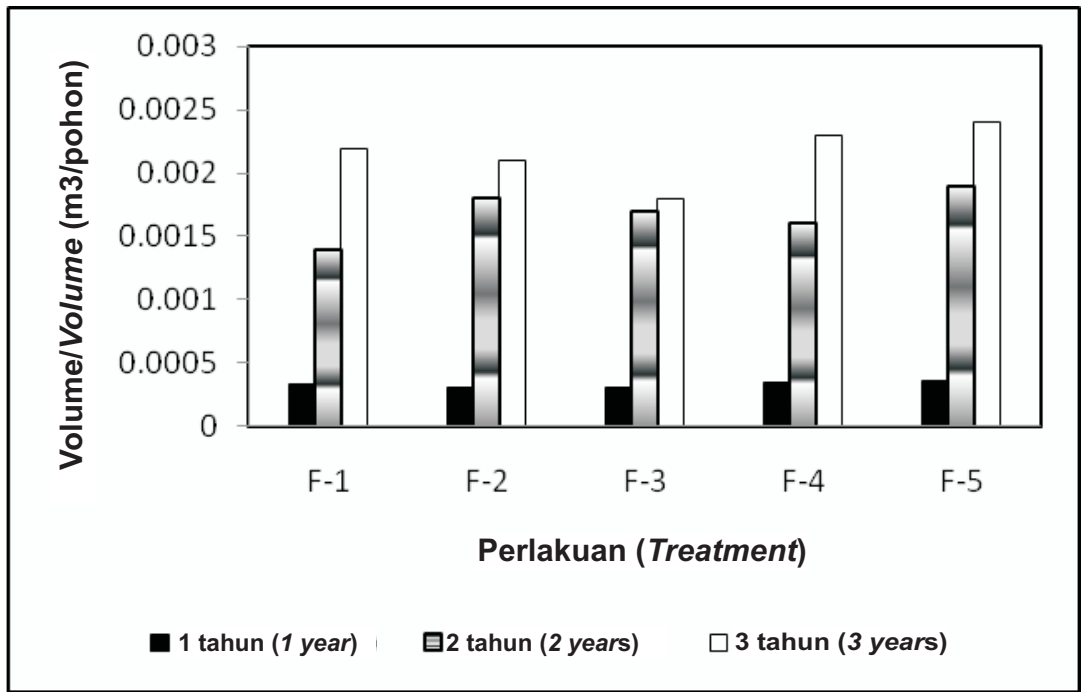

(c)

Gambar(Figure)2. Tinggi (a), diameter batang (b) dan volume (c) tanaman jati pada beberapa perlakuan (The height (a), stem diameter (b), and volume (c) of teak on the several treatments). Keterangan (Notes): Angka-angka dalam kolom yang sama pada diagram batang yang diikuti dengan huruf sama tidak berbeda nyata pada taraf kepercayaan $95 \%$ (Figures in the same column and on the column diagram followed by the same letters are not significant at $95 \%$ confidence level based on the Duncan's multiple range test) 
Manipulasi lingkungan berupa pemberian pupuk kandang dan variasi ukuran lubang tanam memberikan pengaruh yang nyata terhadap pertumbuhan jati (Tabel 2). Pertumbuhan tanaman cenderung semakin baik dengan bertambahnya ukuran lubang tanam. Hal yang sama dikemukakan oleh Sternberg, et al. (2000) pada pinus, Schwan (1994) pada Picea mariana dan P. glauca. Ukuran lubang tanam yang relatif besar secara langsung akan menciptakan media tumbuh yang lebih baik karena memiliki pori-pori tanah yang lebih banyak sehingga meningkatkan aerasi dan drainase tanah. Tanah yang memiliki drainase dan aerasi baik umumnya memiliki pori-pori tanah sekitar $50 \%$ dimana pori-pori mikro akan diisi air dan pori-pori makro ditempati udara (Soepardi, 1983). Tanah di Hutan Penelitian Parungpanjang kandungan liatnya mencapai lebih 70\% (Lampiran 1). Tanah tersebut merupakan tanah bertekstur halus dan sulit diolah (Soepardi, 1983). Menurut Hardjowigeno (2003), pada tanah-tanah yang bertekstur halus, pengolahan tanah sangat diperlukan untuk memperbaiki porositas tanah. Pembuatan lubang tanam yang optimal dapat dikategorikan sebagai teknik pengolahan tanah sehingga mampu memberikan kondisi lebih baik bagi pertumbuhan tanaman jati yang umumnya lebih menyukai tanah berporositas tinggi.

Menurut Switzer (1960), ukuran lubang tanam yang optimum berbeda untuk setiap jenis dan kondisi tanah. Beberapa penelitian mengemukakan bahwa pada tanah yang padat, ukuran lubang tanam optimal disarankan 5 kali diameter gulungan akar (Clatterbuck, 2000). Ukuran lubang yang lebih kecil dari 30 × 30 × $30 \mathrm{~cm}$ tidak memberikan hasil yang berbeda secara signifikan terhadap pertumbuhan Acacia auriculiformis dan Hopea odorata (Hossain dan Paul, 1998), sedangkan hasil penelitian lainnya menunjukkan bahwa ukuran kedalaman lubang tanam $40 \mathrm{~cm}$ memberikan pertumbuhan yang lebih baik untuk bibit Cupressus sempervirens dibandingkan kedalaman lubang tanam $20 \mathrm{~cm}$ (Tabari dan Saeidi, 2008).

Kondisi tanah di Parungpanjang dapat dikategorikan mempunyai tingkat kesuburan rendah (Pusat Penelitian Tanah dan Agroklimat, 1991). Hasil analisis tanah menunjukkan bahwa kandungan N sedangrendah (0,16-0,30\%), P sedang-tinggi (0,38-0,51 ppm), Ca rendah (2,39-3,97 me/100g), Mg tinggi (3,50$5,54 \mathrm{me} / \mathrm{g}$ ), dan K rendah-sedang $(0,24-0,53)$ (Pusat Penelitian Tanah, 1983). Pada tanaman muda, kandungan $\mathrm{N}$ lebih berperan dalam meningkatkan pertumbuhan (Williams, 1988 dalam Clatterbuck, 2000). Hasil analisis tersebut juga menunjukkan bahwa blok 1 relatif memiliki kualitas tanah yang lebih baik yang dapat dilihat dari kandungan $\mathrm{N}, \mathrm{Ca}, \mathrm{Mg}, \mathrm{K}, \mathrm{pH}$ yang lebih tinggi yang menyebabkan pertumbuhan tanaman pada blok I lebih baik.

Pemberian pupuk harus dilakukan secara efisien karena memberian pupuk yang berlebihan kemungkinan tidak memberikan hasil yang signifikan dan akan meningkatkan biaya operasional penanaman. Pada penelitian ini pemberian pupuk kandang $3 \mathrm{~kg}$ dan $4 \mathrm{~kg}$ tidak memberikan perbedaan yang nyata sehingga dalam aplikasinya, dosis pupuk $3 \mathrm{~kg}$ secara ekonomi lebih efisien. Hal yang sama dilaporkan oleh Yassir dan Omon (2007), dari 4 dosis pupuk kandang yang dicoba (1 kg, $2 \mathrm{~kg}, 3 \mathrm{~kg}$, dan 4 $\mathrm{kg}$ ), dosis $2 \mathrm{~kg} / \mathrm{lubang}$ tanam memberikan pertumbuhan yang optimal. Pupuk kandang termasuk pupuk

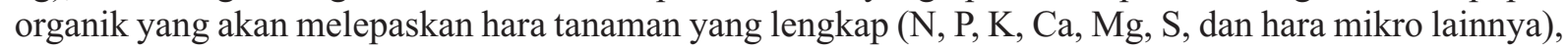
memperbaiki struktur tanah, meningkatkan daya menahan air, memperbaiki permiabilitas tanah, meningkatkan KTK, dan memperbaiki kehidupan biologi tanah. Namun, untuk lebih meningkatkan pertumbuhan tanaman jati diperlukan pemberian dolomit mengingat $\mathrm{pH}$ tanahnya sangat rendah $(4,3-4,7)$ dan dikategorikan sesuai marjinal untuk pertumbuhan jati (Wahyuningrum et al., 2003).

\section{KESIMPULAN}

1. Pemberian pupuk kandang yang lebih banyak (dosis $5 \mathrm{~kg}$ dan $4 \mathrm{~kg}$ ) pada ukuran lubang tanam yang besar $(75 \times 75 \times 75 \mathrm{~cm})$ memberikan persentase hidup dan pertumbuhan tanaman jati yang lebih baik.

2. Perlakuan F4 (ukuran lubang tanam $75 \times 75 \times 75 \mathrm{~cm}$ dengan $4 \mathrm{~kg}$ pupuk kandang) dapat dipertimbangkan untuk untuk diterapkan dalam meningkatkan keberhasilan penanaman jati di Parungpanjang yang memiliki tanah padat dan miskin hara. Perlakuan tersebut menghasilkan persen hidup $92 \%$, tinggi $5,4 \mathrm{~m}$, diameter $7,1 \mathrm{~cm}$, dan volume pohon $0,0023 \mathrm{~m}^{3}$ pada umur tanaman 3 tahun. 


\section{DAFTAR PUSTAKA}

Clatterbuck, W.K. 2000. Post-planting Tree Care: Fallacies and Recommendations. SP 574. Agricultural Extention Service. The University of Tennessee.

Danu, D.J. Sudrajat, dan S. Marantika. 2006. Pertumbuhan Awal Tanaman Jati (Tectona grandis Linn f.) Hasil Kultur Jaringan di Rumpin, Bogor. Buletin Puslitbang Perhutani. Vol. IX No. 1. Pusat Penelitian dan Pengembangan Perhutani. Cepu.

Hardjowigeno, S. 2003. Ilmu Tanah. Penerbit Akademika Pressindo. Jakarta.

Hendromono. 1996. Pterygota alata, Jenis Eksotik yang Menjanjikan: Teknik Penanaman dan Hasil Introduksi. Sylva Tropika No. 6, Desember 1996. Badan Penelitian dan Pengembangan Kehutanan. Jakarta.

Hossain, A.T.M.E., dan S.P. Paul. 1998. Approach to Tree Plantation by Auger Hole Method. Bangladesh Forest Research Institute. Chittagong. Bangladesh.

Otsamo, A., G. Adjers, T.S. Hadi, J. Kuusipalo, K. Toumela, and R. Voukko. 1995. Effect of Site Preparation and Initial Fertilization Tree Species Used in Reforestation on Imperata cylindrical (L.) Beauv. Dominated Grasslands. Forest Ecology and Management. 73 : 271-277.

Pusat Penelitian Tanah dan Agroklimat. 1991. Pengambilan dan Pengujian Sampel Tanah di Hutan Penelitian Parungpanjang. Laporan Kerjasama Pusat Penelitian Tanah dan Agroklimat dengan Balai Teknologi Perbenihan. Bogor.

Pusat Penelitian Tanah. 1983. Petunjuk Teknis Evaluasi Lahan. Laporan Kerjasama antara Pusat Penelitian Tanah dengan Proyek Pembangunan Penelitian Pertanian Nasional, Badan Litbang Pertanian, Bogor.

Rimbawanto, A. 2000. Komersialisasi Bibit Jati Kultur Jaringan, Potensi dan Resikonya. Duta Rimba. No.242/XXIV Agustus 2000. Perum Perhutani. Jakarta.

Rosmarkam, A. dan N.W. Yuwono. 2002. Ilmu Kesuburan Tanah. Penerbit Kanisius. Yogyakarta.

Sadharjo.2001. Pusat Jati dan Bibit Unggul Jati Plus Perhutani. Duta Rimba. No.258/XXV-Desember 2001. Perum Perhutani. Jakarta. P 22-23.

Santoso, B. 1997. Pedoman Teknis Budidaya Eboni (Diospyros celebica Bakh.). Informasi Teknis No. 6. Balai Penelitian Kehutanan Ujung Pandang.

Schwan, T. 1994. Planting Depth and Its Influence on Survival and Growth. A Literature Review with Emnphasis on Jack Pine, Black Spruce and White Spruce. Technical Report TR-01. Ontario.

Soepardi, G. 1983. Sifat dan Ciri Tanah. Fakultas Pertanian. Institut Pertanian Bogor. Bogor.

Sternberg, M., D. Danin, dan I. Noy-Meir. 2000. Effect of Clearing and Herbicide Treatment on Coniferous Seedling Establishment and Growth in Newly Planted Mediterranean Forests. Forest Ecology and Management. 148:179-184.

Sukresno, U.H. Murtiono, A.B. Supangat dan C.N.S. Priyono. 2003. Pengaruh Pengelolaan Hutan Jati terhadap Tata Air: Studi Kasus di Subdas dalam Kawasan Hutan Jati (Modang dan Cemoro) dan Luar Kawasan Hutan Jati (Grojogan). Temu Lapang dan Ekspose Hasil-hasil Penelitian UPT Badan Litbang Kehutanan Wilayah Sumatera. Palembang, 9-10 Desember 2003.

Surata, I.K., dan Widnyana, I.M. 2001. Teknik Budidaya Gaharu. Aisuli No. 14. Balai Penelitian Kehutanan. Kupang.

Switzer, G.L. 1960. Expose and Planting Depth Effects on Loblolly Pine Planting Stock on Poorly Drained Sites. Journal of Forestry. 58:390-391.

Tabari, M., dan H.R. Saeidi. 2008. Restoration of Deforested Areas by Cypress Seedling in Southern Coast of Caspian Sea (North of Iran). Research Note. Ekologi. 67:60-64. 
Wahyuningrum, N., C. Nugroho S.P., Wardojo, B. Harjadi, E. Savitri, Sudimin, dan Sudirman. 2003. Klasifikasi Kemampuan dan Kesesuaian Lahan. Info Das. No. 15. BPTP DAS Surakarta.

Yassir, I. Dan R. M. Omon. 2007. Pengaruh Dosis Pupuk Organik terhadap Pertumbuhan Mahoni (Swietenia macrophylla King) pada Lahan Alang-alang. Balai Penelitian Teknologi Perbenihan Samboja.

Yulianti, B. dan Buharman. 2002. Quo Vadis Mutu Jati Unggul. Klik Benih No. 1. Balai Teknologi Perbenihan. Bogor. 
Lampiran(Appendix) 1. Hasil analisis tanah pada 4 blok uji penanaman (Result of soil analysis on 4 blocks of planting test)

\begin{tabular}{|l|c|c|c|c|}
\hline $\begin{array}{l}\text { Karakter tanah } \\
\text { (Soil characteristics) }\end{array}$ & $\begin{array}{c}\text { Blok } \\
(\text { Block }) 1\end{array}$ & $\begin{array}{c}\text { Blok } \\
(\text { Block }) 2\end{array}$ & $\begin{array}{c}\text { Blok } \\
(\text { Block }) 3\end{array}$ & $\begin{array}{c}\text { Blok } \\
(\text { Block }) 4\end{array}$ \\
\hline $\mathrm{pH}(\mathrm{H} 2 \mathrm{O})$ & 4,7 & 4,3 & 4,5 & 4,4 \\
\hline $\mathrm{N}$ total $(\%)$ & 0,30 & 0,16 & 0,17 & 0,22 \\
\hline P tersedia Bray I-II/available $(\mathrm{ppm})$ & 0,38 & 0,51 & 0,45 & 0,38 \\
\hline $\mathrm{Ca}(\mathrm{me} / 100 \mathrm{~g})$ & 3,97 & 2,39 & 3,08 & 3,25 \\
\hline $\mathrm{Mg}(\mathrm{me} / 100 \mathrm{~g})$ & 5,54 & 3,50 & 3,80 & 4,41 \\
\hline $\mathrm{K}(\mathrm{me} / 100 \mathrm{~g})$ & 0,53 & 0,24 & 0,41 & 0,35 \\
\hline Pasir/sand $(\%)$ & 13,6 & 15,5 & 15,7 & 15,7 \\
\hline Debu/dusk $(\%)$ & 9,5 & 10,5 & 11,1 & 11,7 \\
\hline Liat/clay $(\%)$ & 76,9 & 74,0 & 73,2 & 72,6 \\
\hline
\end{tabular}

Lampiran(Appendix) 2. Hasil uji F pengaruh perlakuan dan blok terhadap pertumbuhan tanaman jati (The result of $F$-test regarding the effect of treatment and block on the growth of teak)

\begin{tabular}{|c|c|c|c|c|}
\hline \multirow{2}{*}{$\begin{array}{c}\text { Parameter } \\
\text { (Parameters) }\end{array}$} & \multirow{2}{*}{$\begin{array}{l}\text { Sumber keragaman } \\
\text { (Sources of variation) }\end{array}$} & \multicolumn{3}{|c|}{ Umur (Ages) } \\
\hline & & $\begin{array}{l}1 \text { tahun } \\
\text { (year) }\end{array}$ & $\begin{array}{l}2 \text { tahun } \\
\text { (years) }\end{array}$ & $\begin{array}{l}3 \text { tahun } \\
\text { (years) }\end{array}$ \\
\hline \multirow{2}{*}{$\begin{array}{l}\text { Persen hidup } \\
\text { (Survival percentage) }\end{array}$} & Perlakuan (Treatment) & $2,010 \mathrm{~ns}$ & $0,732 \mathrm{~ns}$ & $0,327 \mathrm{~ns}$ \\
\hline & Blok (Block) & $0,433 \mathrm{~ns}$ & $1,022 \mathrm{~ns}$ & $3,557 *$ \\
\hline \multirow{2}{*}{$\begin{array}{l}\text { Tinggi } \\
(\text { Height })\end{array}$} & Perlakuan (Treatment) & $4,810 * *$ & $18,983 * *$ & $12,192 * *$ \\
\hline & Blok (Block) & $13,117 * *$ & $34,276 * *$ & $425,262 * *$ \\
\hline \multirow{2}{*}{$\begin{array}{l}\text { Diameter batang } \\
\text { (Stem diameter) }\end{array}$} & Perlakuan (Treatment) & $3,732 *$ & $14,136 * *$ & $8,165 * *$ \\
\hline & Blok (Block) & $10,395 * *$ & $26,962 * *$ & $632,153 * *$ \\
\hline \multirow{2}{*}{$\begin{array}{l}\text { Volume pohon } \\
\text { (Tree volume) }\end{array}$} & Perlakuan (Treatment) & $3,065 *$ & $13,711 * *$ & $7,736 * *$ \\
\hline & Blok (Block) & $9,893 * *$ & $28,490 * *$ & $355,977 * *$ \\
\hline
\end{tabular}

Keterangan (Notes): **=Berpengaruh nyata pada tingkat kepercayaan 99\% (Significant at 99\% confident level) $*=$ Berpengaruh nyata pada tingkat kepercayaan 95\% (Significant at $95 \%$ confident level) ns $=$ Tidak berpengaruh nyata (Non significant $)$ 